\title{
THE POTENCY OF $\triangle F$ 508-T GEN MUTANT THE CODING OF CYSTIC FIBROSIS TRANSMEMBRANE CONDUCTANCE REGULATOR (CFTR) AS PROTOTYPE AT THE CONGENITAL BILATERAL ABSENCE OF VAS DEFERENS (CBAVD) DISEASE IN INDONESIA
}

\section{Maslichah Mafruchati , Mas'ud Harijadi², Widjiati , and Boerhan Hidayat ${ }^{4}$}

${ }^{1}$ Student

${ }^{2}$ Department of Reproduction Veterinary Science

${ }^{3}$ Department of Anatomy Veterinary Anatomy

${ }^{4}$ Director of Specific Infection Hospital Airlangga University

Faculty of Medicine, Airlangga University

\section{Abstract}

Corresponding Author: Maslichah Mafruchati

Received: 03 October 2017 Accepted: 10 October 2017

Published: 29 November 2017

Publishing services provided

by Knowledge

(c) Maslichah Mafruchati et al. This article is distributed under the terms of the Creative Commons Attribution License, which permits unrestricted use and redistribution provided that the original author and source are credited.

Selection and Peer-review under the responsibility of the VMIC Conference Committee.
Birth defect (congenital defect / congenital condition) is an anomaly appearing at birth and able to cause the physical or mental defect or death. Birth defect generally can be detected during the prenatal period. However, if this cannot be detected during the prenatal period, it can be identified at the post natal examination. Congenital Bilateral Absence Vas Difference (CBAVD) is of one the congenital defects characterized by Azoospermia causing the occurrence of infertility. This congenital defect can bring impact to the structural, functional and metabolism anomalies. Approximately 7.9 million children in the world (about $6 \%$ of the whole anomalies in the world) were born with serious congenital defects every year due to genetic anomaly or other post-conception. The determination of optimal output from PCR optimization to obtain the location of $\Delta \mathrm{F}$ 508-T mutant on CBAVD patients in Indonesia is conducted pursuant to the gene target. The conclution were influence of various factors as the indicator specifying the mutation of $\Delta \mathrm{F}$ 508-T mutant needs to be considered in making a decision for the preliminary research on CBAVD in Indonesia.

\section{INTRODUCTION}

The Congenital Bilateral Advance Vass Diferens (CBAVD) is one of the congenital defects characterized by Azoospermia. The rate of CBAVD occurrence is certainly very small, namely around 2-10\%. 
This congenital defect can bring impact to the anomaly in structure, function or metabolism. Each year about 7.9 million children all over the world (approximately $6 \%$ of the whole births in the world) are born with serious congenital defects due to genetic anomaly or other post conceptual causes, such as alcoholic, rubella, syphilis, iodine deficiency and the like. According to Center for Disease Control and Prevention (CDC), each year in USA about $3 \%$ of the children are born with various congenital defects and about 1 out of 5 (five) babies with the congenital defects will death on the first year of their life. There is still no data about the case of CBAVD congenital diseases in Indonesia. The CBA patients have high rate of success and relatively lower level of morbidity. The infertility on men still becomes the case not yet been thoroughly settled in Medical Science, so that the priority is not only given to carry out the genetic test to the patients, but also the etiology identification and counseling should already have been socialized to prevent the transmission of genetic defects through ART - Assisted Reproductive Technology.

It is expected that with the activation of the Assisted Reproductive Technology, the evaluation on infertility on men either syndrome or non-syndrome through the Diagnostic Test will be more improved (Dada, 2011). The causes of infertility on men have been investigated and examined by Hotchkiss since the Year 1944 through various researches already been conducted till finally the case of CBAVD was found in South America by Michelson et al., 1949. The recommended data on various genetic test on infertility cases focused on the examination outputs on abnormal spermatozoa, either quantitatively or qualitatively caused by the genetic mutation based on their phenotype and their genotypes constitutes the CBAVD patients (67\%) accompanied by the presence of CFTR. (Dada, 2011).

The research development on CBAVD at the international level has started since the year 1968 by the finding of an American man who died due to an abscess growing bigger and bigger at the scrotum and the formation of fibrosis cystic already been metastasis at various organs, particularly at pancreas, lung, liver and his death was presumed due to the immunodeficiency. (Wang et al., 2002).

\section{METHOD OF RESEARCH}

PBMC experimental unit is taken from one person declared suffering from CBAVD. The RNA isolation was conducted to see the expression of CFTR gene, the mRNA available inside the cell indicating the presence of CFTR protein. In order to obtain the DNA, the RNA has to be changed first to be cDNA. The established DNA is then transferred to plasmid. 
The execution of this research is classified into 4 stages namely: First, isolation, characterization and culture of PBMC. Second, DNA transfection into the target cell. Third, CFTR gene design as prototype resistant to CBAVD infection. Fourth, analysis on the resistance to CBAVD infection. The proposal of research is presented to the Ethical Commission of LPPM (Institution of Research and Community Dedication) of Airlangga University. Having been approved, the UE is taken from PBMCs of the person suffering from CBAVD. UE is isolated by 1.077 Ficoll gradient and hermatopoetic culture cell. Then, the degree of mRNA is identified. Further, the mRNA extraction is carried out at PCR. If the PCR is positive, a purification is carried out again and given the labeling and sequencing.

\section{Polymerase Chain Reaction (PCR)}

PCR is conducted through several stages, namely: DNA extraction, amplification and electrophoresis. The DNA extraction is conducted from culture cell in which the culture cell at the amount of $10^{3}$ cells at the final volume of $200 \mu$ buffer B3 (a mixture of B1 (containing Guanidin Hydrochloride) and $\mathrm{B}_{2}$ ) is incubated at the temperature of $70^{\circ} \mathrm{C}$ for $10-15$ minutes. Further, it is added with $96 \%$ ethanol at the amount of $210 \mu$, then given the vortex

The next step is BNA bind. This mixture is entered into the column then centrifuged $11,000 \mathrm{~g}$ for 1 minute. The liquid at the bottom is discharged and cleaned twice (2x).

First, by adding $500 \mu$ l buffer BW (Guanidin Hydrochloride and Isoprotenol $<25 \%$ ) then centrifuged $11,000 \mathrm{~g}$ for 1 minute then discharged. The second cleaning is conducted by adding $600 \mu$ buffer B5, then centrifuged for 1 minute. The entering liquid into the collecting tube is discharged (Rantam et al., 2011). Centrifugal rotation of 11,000 $\mathrm{g}$ is repeated for 1 minute to clean up the ethanol. Then the column is put into the $1.5 \mathrm{ml}$ tube eppendorf and added with $100 \mu$ lelution buffer already been heated at the temperature of $70^{\circ} \mathrm{C}$ and incubated for 1 minute, then centrifuged 11,000 $\mathrm{g}$ for 1 minute. In principle, PCR consists of three stages, namely: denaturalization of multiple chain of DNA, then primary annealing (attachment) to DNA of its target. The last stage is the primary extension due to the presence of DNA polymerase. The DNA output is the exponential accumulation of the specific DNA target. There are 3 stages in amplification, namely denaturalization conducted by means of incubation at waterbath at the temperature of $95^{\circ} \mathrm{C}$. The next stage is annealing, namely the attachment process of primary to the template conducted at the temperature of $47^{\circ} \mathrm{C}$. The last is the extension stoge, namely the extension process of nucleotide base chain at the temperature of $72^{\circ} \mathrm{C}$ so that 2 new multiple chains of DNA are established. 
Immunoglobulin $\mathbf{G}$ and Immunoglobulin $\mathbf{A}$ is carried out at the research. Immunoglobulin or antibody is a group glycoprotein available at the serum or liquid at the body of almost all the mammalians. Immunoglobulin includes in the glycoprotein family having the same basic structure, consisting of $82-96 \%$ of polypeptide and $4^{-}$ $18 \%$ of carbohydrate. The polypeptide component brings the aforesaid biologic nature of antibody molecules. The immunoglobulin A $(\operatorname{lgA})$ is the antibody found at the parts of body, such as at the nose, respiratory channel, digesting channel, ears, eyes, and vagina. The IgA antibody protects the surface of the body from the foreign substance from outside. This type of antibody is also found at the saliva, tears and blood. About $10 \%$ till $15 \%$ of antibody inside the body is the IgA antibody. A small amount of people do not produce the IgA antibody.

The Adenovirus examination is carried out to detect the CBAVD case caused by the Adenovirus. Adenovirus can have latent nature in its host for several years. The presence of protein penton from adenovirus with the virulent nature on its host without any synthesis hindrance from the cell, so that it causes the cell released and separated from the monolayers. The latent nature of adenovirus has to be taken into our attention. Although its clinical symptoms are frequently non-visible at the patients, the virus remains exists at the body of the patients. In general, the virus can be found at the lymphoid tissue (lymph gland, tonsil, and peyer's patches). The Adenovirus virus examination is conducted to prove that the CBAVD case is caused by Adenovirus of genetic defect.

\section{RESULTS}

The structure of growth or development and reproduction functions of organism depends on protein materials available in every cell and tissue. A protein consists of one or more chains of amino acids. Each chain of amino acid is called 'polypeptide', and the sequence of amino acids in polypeptide chain is coded by a gene. Not all genes become the protein synthesis, so that not all gene transcriptions constitute RNA which is then translated.

Figure 1: The reseach trial with different three primer are C cDNA (red), M cDNA (yellow) and N cDNA (blue) to obtain many kinds primer that available to detect cDNA level accuratedly with amplificatons, The reprecentative primer is N cDNA (blue) and un representative is $\mathrm{C}$ cDNA (red)

Figure 2. Replication of PCR was done several times to obtain optimum band that appropiate with PCR result of Werstern people 
TABLE 1: The result of measurement RNA level in CBAVD patient.

\begin{tabular}{|c|c|}
\hline Measurement & Level \\
\hline Wavelenght (1) & $260 \mathrm{~nm}$ \\
\hline Absorbance & $0,121 \tilde{A} U$ \\
\hline Wavelenght (2) & $280 \mathrm{~nm}$ \\
\hline Absorbance (2) & $0,099 \tilde{A} U$ \\
\hline Concentration & $0.1214 \mu / \mathrm{ml} \times 200=24,28 \mu / \mathrm{ml}$ \\
\hline Dilution Factor & 1.0000 \\
\hline Level of Cdna & $\tilde{A} 260 / \tilde{A} 280=1,2235$ \\
\hline Path Length & $M$ \\
\hline
\end{tabular}

TABLE 2: The result of measurement of RNA level in CBAVD patient.

\section{Nama Sampel}

Darah penderita CBAVD
$\mathrm{A} 260(\mathrm{AU}) \mathrm{A} 280(\mathrm{AU})$

0,1214

0,099

1,2235

$24,28 \mu \mathrm{g} / \mathrm{ml}$

Figure 3: Result showed negative adenovirus appear of PCR. bands features of adenovirus was not appear, primer of adenovirus with white band colour.

Line 4 : marker

protein Line 1,2,3,5,6,7,8,9,10 : sample

protein CFTR

$A: \pm 190-200$

$\mathrm{kDa}$

$B: 170-180$

TABLE 3: The measurement of CDNA level in CBAVD patient.

Measurement Level
Wavelenght (1) $260 \mathrm{~nm}$
Absorbance (1) $0,024 \tilde{\mathrm{A} U}$
Wavelenght (2) $280 \mathrm{~nm}$
Absorbance (2) $0,025 \tilde{\mathrm{AU}}$
Concentration $0.0240 \mu \mathrm{g} / \mathrm{ml}$ X $200=4,8 \mu \mathrm{g} / \mathrm{ml}$
Dilution Factor 1.000
Level of cDNA $\tilde{\mathrm{A}} 260 / \tilde{\mathrm{A}} 280: 0,9540$
Path Length $\quad 1.00 \mathrm{~cm}$


TABLE 4: The result of measurement cDNA level in CBAVD patient.

\begin{tabular}{|c|c|c|c|c|}
\hline Nama Sampel & $A 260(A U)$ & $A 280(A U)$ & $\mathrm{A} 260 / 280$ & Konsentrasi $(\mu \mathrm{g} / \mathrm{ml})$ \\
\hline эга & 0 & & $0,0250,9540$ & 4,8 و / ml \\
\hline
\end{tabular}

TABLE 5: Profile of PCR in reverse mRNA to cDNA procces.

\begin{tabular}{|c|c|}
\hline Cycle & Cycle Point \\
\hline Hold@ & \\
\hline $95^{\circ} \mathrm{C}, \mathrm{O}$ & \\
\hline $\min 15$ & \\
\hline secs & \\
\hline Cycling & Step $1 @ 95^{\circ} \mathrm{C}$, hold 15 \\
\hline (40 repeats) & secs \\
\hline & Step 2 @ $45^{\circ} \mathrm{C}$, hold 15 \\
\hline & secs \\
\hline & Step 3 @ 60 c, hold 45 \\
\hline & secs, acquiring to \\
\hline & Cycling $A([$ Green,1,1]) \\
\hline
\end{tabular}

TABLE 6: The parameter of amplifications cDNA procces in Rotor-Gene Mechine.

\begin{tabular}{|c|c|}
\hline Step & Result \\
\hline Run Name & IKA CDNA C M N \\
\hline Run Start & 1/17/2014 10:29:03 AM \\
\hline Run Finish & 1/17/2014 12:12:46 PM \\
\hline \multicolumn{2}{|l|}{ Operator } \\
\hline \multicolumn{2}{|l|}{ Notes } \\
\hline Run On Software Version & Rotor-Gene 2.0.2.4 \\
\hline Run Signature & The Run Signature is valid. \\
\hline Gain Green & 9.33 \\
\hline Left Threshold & 1.000 \\
\hline Standard Curve Imported & No \\
\hline Standard Curve (1) & N/A \\
\hline Standard Curve (2) & $N / A$ \\
\hline Start normalising from cycle & 1 \\
\hline Noise Slope Correction & Yes \\
\hline No Template Control Threshold & $0 \%$ \\
\hline Reaction Efficiency Threshold & Disabled \\
\hline Normalisation Method & Dynamic Tube Normalisatio \\
\hline Digital Filter & Light \\
\hline Sample Page & Page 1 \\
\hline
\end{tabular}


TABLE 7: Profile of PCR programm in amplificate cDNA procces.

\begin{tabular}{l|l} 
Cycle & Cycle Point \\
Hold @ $95^{\circ} \mathrm{C}$, & \\
o min 15 secs & Step 2 @ $45^{\circ} \mathrm{C}$, hold 15 secs \\
Cycling (40 repeats) & Step 1 @ $95^{\circ} \mathrm{C}$, hold 15 secs \\
& Step 3 @ $60^{\circ} \mathrm{C}$, hold 45 secs, \\
& acquiring to \\
\hline Cycling A([Green, 1,1$])$
\end{tabular}

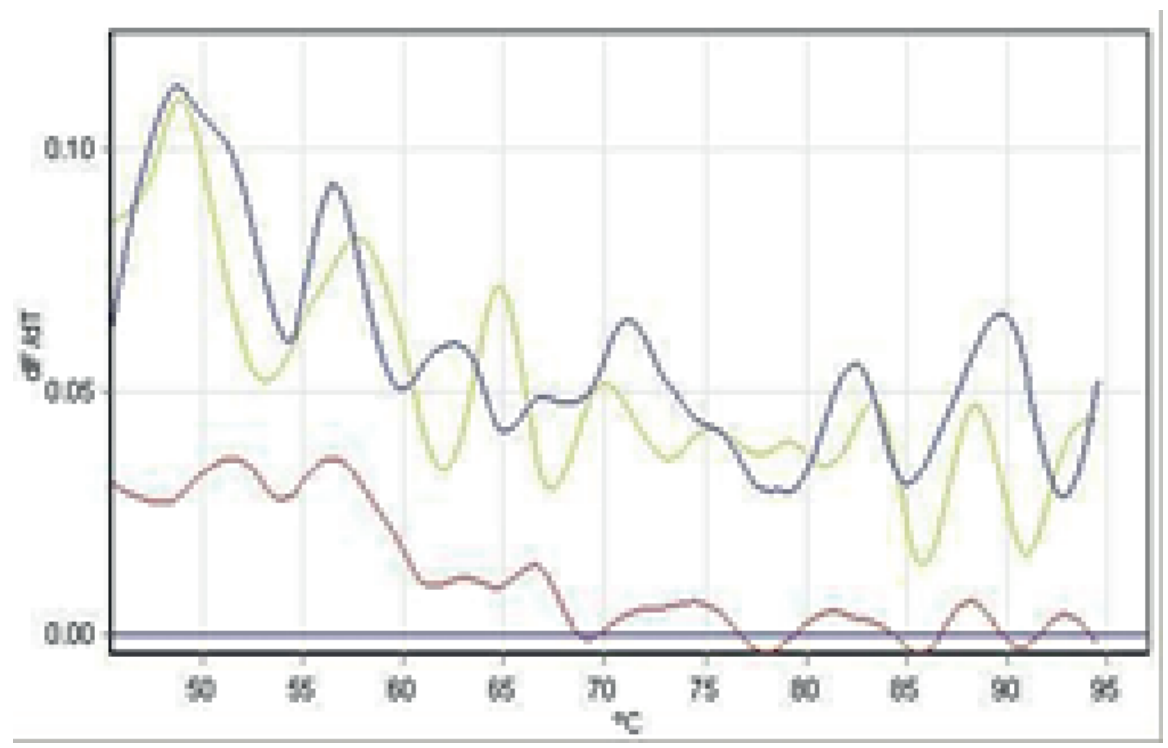

Figure 1: Graphic of the result reverse mRNA.

$\mathrm{kDa}$

C : $140-160$

$\mathrm{kDa}$

$\mathrm{D}: \pm 120 \mathrm{kDa}$ 


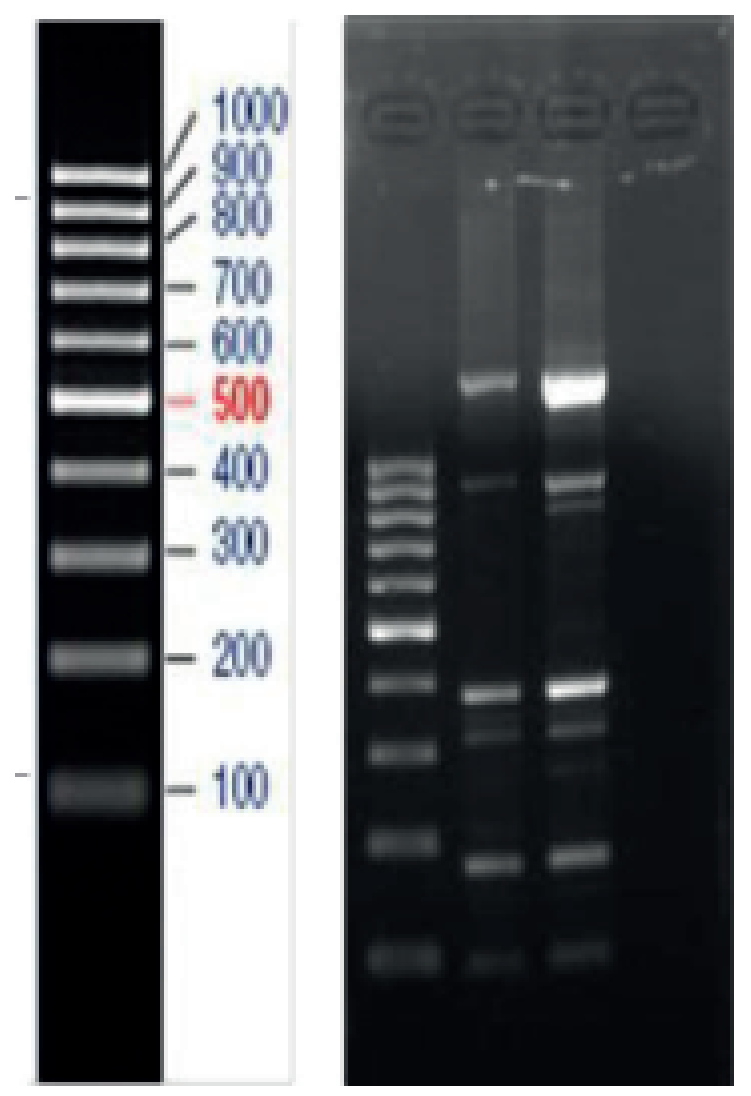

Figure 2: Result of PCR.

TABLE 8: The Result of Imunoglobulin G and Imunoglobulin A examination.

\begin{tabular}{|c|c|c|c|c|}
\hline Measurement & Result of Concentration & Value Refference & Apparatus & Methode \\
\hline $\lg G$ & $1579 \mathrm{mg} / \mathrm{dL}$ & $700-1600 \mathrm{mg} / \mathrm{dL}$ & Cobas $C 6000$ & Imuno turbidimetri \\
\hline I $A$ & $222 \mathrm{mg} / \mathrm{dL}$ & $70-400 \mathrm{mg} / \mathrm{dL}$ & Cobas $C 6000$ & Imuno turbidimetri \\
\hline
\end{tabular}

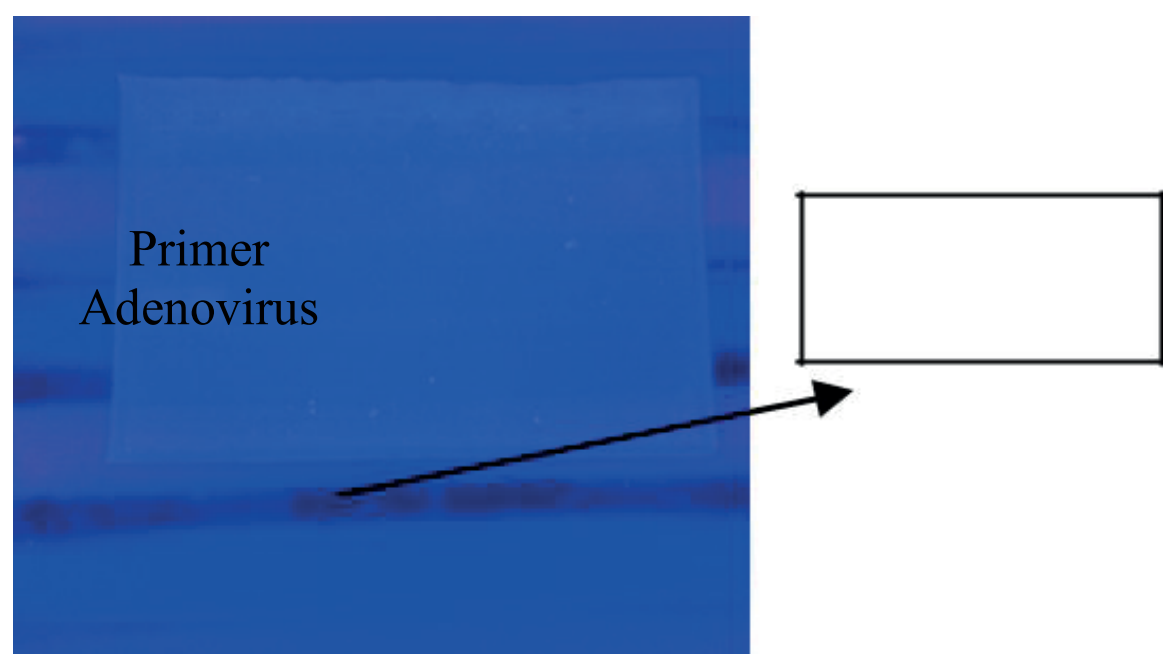

Figure 3 


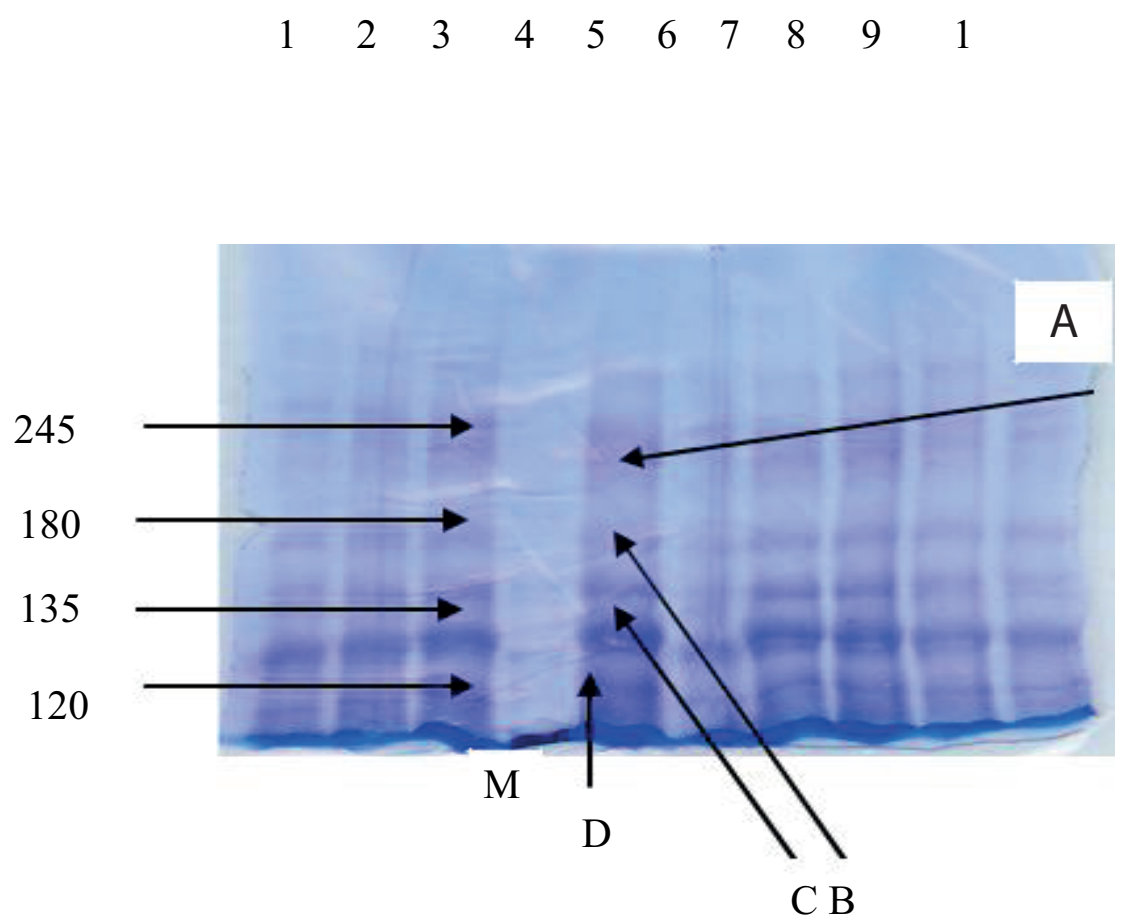

Figure 4: Result of SDS - PAGE CFTR Protein.

\section{DISCUSSION}

According to Center for Disease Control and Prevention (CDC), in US there are about 3\% children born suffering from various congenital defects every year and about 1 out of 5 babies with those congenital defects will die on their first year of living. The congenital defect in Indonesia constitutes one of the causes of death of new born babies and if it is not handled properly and quickly, it will become the lifelong defect able to increase the rates of sickness and mortality of babies in Indonesia (WHO, 2010).

Infertility in men is still the case not yet having been completely and thoroughly handled in Medical Science. Therefore, it is not only prioritized to do the genetic test to the patient. Also, the etiology identification as well as the counseling shall have been socialized in order to prevent the transmission of genetic defect through Assisted Reproductive Technology (ART). The rate of CBAVD occurrence is certainly very small, namely around $2-10 \%$. However, if it is not properly handled, it will trigger the occurrence of a problem, particularly the good harmony of a household.

The infertility identified by Azoospermia can be corrected through the surgery and non-surgery actions. However, the surgical action still requires further experience and research. In addition, there are many congenital defects unable to be given a therapy or die at the early ages. Congenital defect can also cause the occurrence of mental disorder. 
In Washington, the CBAVD cases are mostly dominated by the White-men. Based on this case, a research was conducted at Pasteur Institute in1983 and it found out that the possible cause of this case was CBAVD. The Diagnostic Research was developed and it produced a Genetic Test Kit acknowledged byFDA at Robert Gallos Laboratory in 1985. The screening program development has been activated pursuant to the speed rate of the CBAVD case by performing "The Preconception and Prenatal Carrier Screening for Cystic Fibrosis" in 2001 for the patient of CBAVD carrier. This was also conducted to new born babies to perform the Newborn Screening through - Initial Screening Test Level of IRT (Immuno Reactive Trypsinogen).

Output of this research proves the 3 different primaries, starting from the holding on the fourth cycle and an increase continuously occurs till the $40^{\text {th }}$ cycle as an illustration of cDNA profile of the CBAVD patients. This research also proves that the CBAVD congenital defect on Indonesian people have the chain of DNA gene CFTR length at about 400 base pair (40obp). Output of this research proves that the abnormal congenital defect of the CBAVD on the Indonesian people has the chain of DNA gene CFTR at the range of 400 base pair (40obp), whereas the European people have 600 base pair (6oobp). The difference in the output of this PCR is possibly influenced by various factors, namely: total amount of samples being researched, research implementation technique covering the duration and temperature during annealing, cycling and replication. Output of the SDS-PAGE analysis to determine the weight of CFTR protein molecule is more or less $190-250 \mathrm{kDa}, 170-180 \mathrm{kDa}, 140-160 \mathrm{kDa}$ and $120 \mathrm{kDa}$. The long term objective of this research is to know how much the base pair of CBAVD case in Indonesia is expected to become the prototype to repair the gene undergoing the mutation as the result of congenital defect. The success of this research can give solution to the problem of CBAVD disease none the congenital defect due to the mutation of $\Delta \mathrm{F}$ 508-T gene coding the CFTR.

The finding of diagnostic through ART for CBAVD motivates the scientists to start developing a research for CBAVD Therapy. In the year 1989, "Gene Testing Going Mainstream" was invented to detect the gene mutation caused by Fibrosis cystic at the white people in Washington. (Wilschanski et al., 2000). At least $97 \%$ of theFibrosiscystic cases on men with infertile condition but not sterile is due to the occurrence of obstruction on ductus efferent and non-development of ductus deferens. As a result it may have the potential to the occurrence of oligospermia, teratospermia, and oligoastheno spermia.

Congenital Bilateral Absence of Vas Deferens (CBAVD) can reduce the volume of spermatozoa then continued to cause the Infertility, so that it is able to decrease the pregnancy. However, ART also has a weakness, namely progenitor supplementation 
that has to be carried out on the gene deletion already been cloned in order to design the prototype on CBAVD disease. In addition, if the CBAVD case is not handled immediately, it may cause the mortality because the fibrosis cystic has already undergone the metastasis to various organs as the effect of gene mutation. CFTR of $\Delta \mathrm{F}$ 508-T mutant is the CFTR having got the deletion from phenylalanine at the position of 508 nucleotide base from the CFTR protein of coding gene at 554-576 region, so that the chronology of amino acids of Isoleucine-Isoleucine-Glycine-Valine formerly from the chronology of Ispoleucine-Isoleucine-Phenylalanine-Glycine-Valine and its nucleotide chronology is ATC-ATT-GGT-GGT formerly from ATC-ATC-CTT-TTT-GGT-GTT (Cheng et al., 1990). The success of this research can give solution to the problem of CBAVD congenital defect as the effect of mutation of $\Delta \mathrm{F}$ 508-T of CFTR coding gene.

The research conducted by (Josserand et al., 2001) since December 1992 until December 1999, 14 infertile male patients are positive CBAVD. The diagnosis that was carried out for CBAVD patients is azoospermia, the size of testes that is smaller than normal, no palpable pulse from vas deference, the ejaculation volume is low, the semen $\mathrm{pH}$ is low, the fructose concentration is low, chlorid concentration $>60 \mathrm{mmol}$, respiratory disturbance, gastrointestinal and hepatobiliary.

This incident and congenital defect are different for different ethnic and race, same goes to the calculation of how big and small the congenital defect is. More than $90 \%$ babies born with serious congenitial defect are born in developed countries. From the perinatal suvey, almost all developed countries has the perinatal ration bigger than $1 \%$ and roughly $25 \%$ from this percentage dies from the direct effect of heavy malformation (Arikrishnan, 2012).

Congenital defect in newly born babies can be one type of defect only or more than one type of defect which is equivalent to multiple congenitial defect. One congenitial defect is not found or not seen yet at newly born babies but these defect will only be detected as the baby grows. As the development of the world of medicine increases, one congenital defect can be identifies since foetus. When there are two or more congenital defect found around 15\% although there are only three or more small congenital defect, the likelihood of finding large congenital defect is as big as $90 \%$. Major structural anomally happens $2-3 \%$ at newly born babies and other than that has $2-3 \%$ happens during 5 years of age or more until the total percentage is $4-6 \%$. Birth defect is the major cause of mortility in babies with the mortility around $21 \%$.

The formation of organ which is known as organigenesis or morphogenesis is a period that is really important to form a definitive individual (foetus). This mean that the individual must have the shape and face that is specific in one species. During organogenesis which is also called embryogenesis is a periode when all the germinal 
layers which is ectoderm, mesoderm and endoderm will form a lot of tissue and specific organs. The gonad and its ducts which is from the mesoderm layer will become three layers which are epimere, mesomere and hipomere. Mesomere will develop into Genitial ridge which will form reproductive organ and the urogenitial system while Neprotome will form the kidney. Primordial germ cell will develop into Genitial Ridge that will develop onto Gonadal Ridge and finally it will develop into gonad and will migrate either pasively or actively until it become uterus, oviduct and vagia while the Wollfian will become epididymis, vas defence and vas efferent (Poernomo dkk., 2012).

CFTR gene functions during the formation of mesonephricus duct until abnormal defect of protein CFTR happens then systic fibrosis gene mutation will occur. The mesonephric duct will not develop which will continue when there is no formation of vas deferensand then, the spermatogenesis process will be affected as the volume of sperm is low and the low quality of sperm. The indicator of systic fibrosis sometimes cannot be diagnosed by CBAVD, then again, CBVAD always can be identidies when there are presence of systic fibrosis (Jiamin, 2012; Ven K, 1996).

Congenital Bilateral Absence of The Vas Deferens (CBAVD) is not very general as this condition have prevalent around 1-2\% from the male population (Durieu and Hollman, 1997). This CBAVD always caused by the obstruction of lateral Vas Deferens(Weiske et al., 2000).

(Casals et al., 2000) reported that 38\% from 138 people that suffer Congenital Unilatreal Absence Vas Deferenshas the relationship between mutation of CFTR and $45 \%$ of patients suffering from this specific gene mutation is not found in cystic fibrosis. This infertility case from 274 infectious male, only 3 that suffers CBAVD.

CFTR will cause systic fibrosis which is also known as mucoviscidosis and also a genetic disease to the Western people which has prevalent 1:2000 of babies. CFTR is due to the disturbance on the fuction of the exocrine gland with the characteristic of this case where there is presence of chronic bronchopulmonary and disturbance of the function of the pancreas. The function of the pancreas will effect the occurence of malabsorbtion and continues when the growth is affected (Zabner et al., 1996).

At (Figure 4) the result of protein analysis to know the molecule weight of protein CFTR at CBAVD patients is done by using SDS PAGE technique to explore the antigent component based on molecule weight. The separation of protein molecule CFTR in polyacrylamide gel is from the electronic mobility from one protein substance until the mass protein separation is formed and the gel sheets is made through chemical polimerisation from acrylamide and bisacrylamide. The CFTR is a primary protein chain that contains 1480 amino acids which functions as cyclic AMP-regulated Cl-channel. 


\section{CONCLUSION}

This research shows that with three different primer which starting with holding at the forth cycle and looking at the increment until the 4 oth cycle as a profile picture of cDNA from CBAVD patients. Then, through this research, the congenital defect in Indonesian people has DNA gene CFTR around 400 base pair (40obp). The difference in this PCR value is maybe due to the factors that influence it like the samples, the technique used during observations that involves time and temperature during annealing and the replication cycle. The weight of the molecule from the analysis are $\pm 190-250$ kDa, $170-180 \mathrm{k} \mathrm{Da}, 140-160 \mathrm{kDa}$ and $120 \mathrm{kDa}$.

\section{ACKNOWLEDGEMENT}

We thanks Dr. Boerhan Hidayat, dr.,Sp.A(K) as a director of Specific Infection Hospital Airlangga University for providing facilities for research.

\section{References}

[1] Arikrishnan. 2012. Congenital Defect. 25 Mei 2014 from http://respiratory.usu . ac.id/bitstream/123456789/37882/4/chapter.2011.pdf.

[2] Casals, T., Bassas, L., Ruiz-Romero, J., Chillo'n, M., Gime'nez, J., and Ramos, MD., MD. 2000. Extensive analysis of 40 infertile patients with congenital absence of the vas deferens: in $50 \%$ of cases only one CFTR allele could be detected. Hum Genet, 95:2011.

[3] Cheng SH, Gregory RJ, Marshall J, Paul D, Souza DW, White GA, O'Riordan CR, and Smith AE. 1990.Defective intracellular transport and processing of CFTR is the molecular basis of most cystic fibrosis. Cell, 63:827-834.

[4] Dada, R. 2011. Genetic Testing in Male Infertility. The Open Reproductive Science Journal, 3(1)42-56.

[5] Depkes 2000. Infant Mortality Rate. Revised 28 May 2014 from http://digilib.unimus.ac.id/dow nloat.php.id=14121

[6] Durieu, E and Hollmann, M.W. 1997. Local anesthetics and the inflammatory response : A new therapeutic indication?. Anesthesiology. 93:858-75

[7] Jianmin, Y. 2012. CFTR mutations in men with CBAVD: a systemic review and metaanalysis. Human Reproduction, 11:25-35.

[8] Josserand, R.N., Omar F.B, Rollet J, Lejeune H, Boggio D, Durand D.V, Durieu I. 2001. Cystic Fibrosis Phenotype Evaluation and Paternity Outcome in 50 Males with 
Congenital Billateral Absence of Vas Deferens. Human Reproduction 16(10):20932097.

[9] Michelson AD, Harrison P, and Keeling D. 1949. Clinicat test of platelets function. Platelets $2^{\text {nd }}$ edition. New York: Elsevier Inc. 2:445-474.

[10] Poernomo B, Mafruchati M, Widjiati, and Luqman E.P. 2012. Embriology Textbook. Airlangga University Press Surabaya, Indonesia. 3rd Edition 18-4

[11] Rantam, F.A. 2011. Applied Immunology Lecture Doctoral Programme, Postgraduate Studies, Airlangga University, Indonesia

[12] Wang, Z., Milunrsity J, Yamin M, Maher T, Oates R, and Aublrey M. 2002. Center for Human Genetics and Departement of Pediatric and Urology. Boston University School Medicine. USA. J. Human Reproductive, 17(8):2006-2072.

[13] Weiske, G., Rodenbeck A, Riemann D, Klein T, Feige B, Horny A, Hummel R, AlShajlawi $A$, and Voderholzer U., 2002, Nocturnal cortisol and melatonin secretion in primary insomnia, Psychiatry Res, 113:17-27.

[14] Wilschanski, M., Dupuis A, Ellis Jarvi K, Zielenski J, Tullis E, S Martin S, Corey M, Tsui L.C., and Durie P. 2006. Mutations in The Cystic Fibrosis Transmembrane Regulator Gene and In Vivo Transepithelial Potentials American Journal of Respiratory and Critical Care Medicine, 174:787-794.

[15] Zabner, Joseph, Ramsey Bonnie W, and Meeker David P. 1996. Repeat Administration of an Adenovirus Vector Encoding Cystic Fibrosis Transmembrane Conductance Regulator to The Nasal Epithelium of Patients witj Cystic Fribrosis. USA. The American Society for Clinical Investigation. 97(6):1504-1511. 